Apuntes Universitarios, 2021: 11(1), enero-marzo

ISSN: 2304-0335 DOI: https://doi.org/10.17162/au.v11i1.544

\title{
Analogía del derecho en la práctica educativa del derecho civil
}

\author{
The analogy of law in civil law educational practice
}

Viktor Mikryukov $^{1 \mathrm{a}}$

Kutafin Moscow State Law University (MSAL), Moscow, Russia ${ }^{1}$

Orcid ID: https://orcid.org/0000-0002-6856-1627

Recibido: 03 de julio de 2020

Aceptado 07 de octubre de 2020

\begin{abstract}
Resumen
El objetivo de esta investigación fue mostrar cuán activamente se aplica el mecanismo de analogía legal en la práctica actual del derecho civil, identificando las razones del papel principal de la analogía legal como herramienta activa en el proceso de administración de justicia. El método de analogía fue considerado como la herramienta clave del objeto del estudio, y junto con los instrumentos jurídicos y técnicos comparativos especiales, el autor aplicó métodos lógicos generales que son característicos de los estudios más civilizados, como el análisis y síntesis, inducción y deducción, comparación y generalización. Además, el autor definió algunos casos importantes que se decidieron mediante la aplicación de analogías legales y pueden constituir la base para futuras investigaciones en el desarrollo de la práctica judicial pertinente. En este sentido, el aporte del autor consiste en un nuevo concepto de la correlación entre el desarrollo y el desglose de los estándares legales y el grado de demanda de analogía legal en la jurisprudencia.
\end{abstract}

Palabras clave: analogía jurídica, derecho civil, ley, justicia, legislación, jurisprudencia.

\begin{abstract}
The objective of this research was to show how actively the legal analogy mechanism is applied in current civil law practice, identifying the reasons for the main role of legal analogy as an active tool in the justice administration process. The method of analogy was considered as the key tool of the object of the study, and together with the special comparative legal and technical instruments, the author applied general logical methods that are characteristic of the most civilized studies, such as analysis and synthesis, induction and deduction, comparison and generalization. Furthermore, the author defined some important cases that were decided by applying legal analogies and may form the basis for future investigations in the development of relevant judicial practice. In this sense, the author's contribution consists of a new concept of the correlation between the development and breakdown of legal standards and the degree of demand for legal analogy in jurisprudence.
\end{abstract}


Keywords: legal analogy, civil law, law, justice, legislation, jurisprudence.

\section{Introduction}

Legal gap is regarded as the key reason for legal uncertainty, which is considered a negative factor and a defect in the legal system that impedes the achievements of the necessary legal results (Davis, 2011). Likewise, are situations that occur when the social relations, included in the subject of civil law, are not directly regulated by law or contract and there is no custom applicable for such relations (Romanenko, 2017), namely, when there is a gap between a fact requiring the reaction of the legislator and relevant regulatory material.

A condition of legal uncertainty is also observed when there is no formal legal gap; however, existing legislation is not able to respond adequately to some "mutations" of social relations, when the latter take new features in specific socio-economic conditions. It is impossible to ignore these characteristics to provide harmonious implementation of basic civil legal principles, such as participants' equality, inviolability of property, freedom of contract, impermissibility of any arbitrary interference with private affairs, the necessity of unhindered exercise of civil rights, and ensuring the guaranty of restoration of violated rights and their legal protection (Civil Code of RF).

Therefore, the author of the present work points out the fundamental importance of striving to achieve absolute legal certainty around civil law responsibility as well as the inadmissibility of denial of justice and ensuring the civil rights protection in terms of the absence of proper regulatory material. In this context, it is worth highlighting such a powerful, traditional (Malyushin, 2015), and the universal (Demin, 2017) creative tool to address legal shortcomings as the analogy of law. Nowadays, the study of the mechanism of the analogy of law depends on the continuous complication of economic life, i.e., the intensification of the implementation of information and telecommunication networks and electronic technologies, the development of robotics and artificial intelligence (Andreev, 2020), and the active genomic research and interventions in the human genome (Bogdanova, Maleina, and Ksenofontova, 2020). Thus, new unidentifiable regulations are being introduced and the number of relations to be included in the sphere of legal impact is increasing. These relations fall outside existing civil law regulation. At the same time, there is no law (or other normative act) that would regulate similar relations, and could be applied for the analogy of law.

\section{Literature review}

The analogy method in legal argument is regarded as a very common, convenient, and effective means to bridge the gap between facts and rule. In the theory of law, the relevant application of legislative rules governing relations similar to the disputed (not directly regulated) is defined as the analogy of law_analogia legis (Weinreb, 2005). According to the 

analogical reasoning under the rules of statutory analogy, a judicial conclusion is drawn from the case that has already been classified (normatively identified) and assessed on another case based on similarities. Therefore, legal norms are applied to the situations that are not direct subjects to the relevant classification (Macagno, 2009). In Russia, the application of civil law by means of analogia legis is directly permitted for civil disputes (Civil Code of RF). If such a legal gap was identified, and it is impossible to apply the analogy of law to overcome it, Section 2 of Article 6 of the Civil Code of the Russian Federation provides a mechanism of the legal analogy - analogia iuris, i.e., the determination of the rights and obligations of the participants in a disputed relationship based on the general principles and meaning of civil law, as well as the requirements of good faith, reasonableness, and justice.

According to juristic theory, legal analogy is established not according to specific norms, but according to the so-called "general principle of law" (Damele, 2014), which is regarded as "more mysterious and puzzling than analogia legis", as it is associated with axiology and the necessity to ensure internal consistency of the legal system (Koszowski, 2017). Therefore, the analogy of law can be an instrumental for the prompt perfection of the law, and can serve as "something more" than the logical device used by the court (Tsikhotsky, 2011). In addition, the analogy of law effectiveness in exercise the subjective potential of the law enforcer (personal experience and worldview) contributes to the resolution of the most difficult legal situations (Shindyapina and Boshno, 2006), ensuring the spirit of law (Anisimov, 2016) and the implementation of the real-immediate, direct-functioning of the basic principles and the meaning of legislation (Kuznetsova, 2006).

The implementation of the mechanism of the analogy of law in making legal decisions contributes to a serious discretion of the executor, which sometimes qualifies analogical reasoning as "a mask for unrecognized judicial lawmaking" (Schauer and Spellman, 2017). Therefore, there is a certain amount of uncertainty in the mechanism of legal impact. Since the tendency to increase the uncertainty in the law is "extreme" (D'Amato, 2010), it is logical to assume that the role of analogia iuris in legal regulation should increase.

In the doctrine, the analogy of law is mostly regarded as "spare", "the worst" (Rovny, 2011) and "exceptional" instrument, used when all other means have been exhausted (Balashov and Mishutina, 2009), which is below the last stage in the hierarchy of permissible civil legal regulations (Braginsky and Vitryansky, 2001). Some authors approved the practice of overcoming legal gaps by means of the analogy of specific rules of the law. However, they pointed out the impossibility or at least undesirability of the implementation of the analogy of law, since the latter is less consistent with the requirements of legality consolidation, and creates the basis for abuse while using discretionary capabilities of the officials that is inevitable in terms of the analogy of law application (Szabo, 1964). 
Contemporary scientists and law practitioners note that although the application of the analogy of law in substantive and procedural matters is not excluded, it is implemented "relatively rarely" (Slepenkova, 2011), "rather rarely" (Malyushin, 2015), "rarely" (Kulakov, 2013), and "extremely rarely" (Alieskerov, 2002). In courts, the analogy of law as a method of overcoming gaps in civil law is applied "sporadically" (Panova, 2012), "inappreciably" (Polyakov, 2014) or "not involved at all" (Bevzenko, 2010). It is noted that when the theoretical considerations about the analogy of law and legal analogy are transferred to the practical aspect of a particular industry, the application of analogy becomes a very controversial institution, which is difficult to implement).

Because of the logical development of this idea, we can conclude that the demand for the analogy of law in resolving civil law disputes will tend to zero or disappear completely. According to such reasoning, as well as in the view of the comments on the threat and destructive nature of the analogy of law, it is worth highlighting that while considering those rare cases that require turning to the analogy, the judges face the complications that can cause certain judicial errors (Balashov and Mishutina, 2009). Therefore, the assumption that it is inappropriate to correlate the analogy of law with the establishment of the legislation meaning, as well as the reasons to exclude the analogy of law from the provisions, are to be considered as grounded and promising. However, relying on a general assessment of analogy as a fundamental process that plays a central role in any legal reasoning (Hunter, 2008) and impacts the entire legal process, it is worth highlighting the falseness of such ideas in terms of both the approach and argumentation.

\section{Materials and methods}

This study is based on the doctrinal analysis of legal premise that follow the legal theories, laws, and judicial practice materials. The key feature of the work is the reference to both the provisions of well-known generalizing acts of the supreme judicial authority as well as judicial acts that were not previously discussed theoretically, and when the executors of law resolved the dispute by means of the analogy of law. A distinctive feature of the methodological basis of the work was the concurrent application of the analogy method and other logical methods of analysis and synthesis, induction and deduction, comparison and generalization, typology and analogy, which are characteristic for civil law research (Luneva, 2015).

\section{Results}

This study refutes the scientifically accepted notion that the consequent complication and itemization of civil legislation will lead to the fact that the analogy of law will not be necessary, and the norm on the admissibility of such a technique by the courts will actually acquire a metaphysical character. 
The idea has been suggested that if the law executor follows the principle of good faith and other basic principles of civil law while solving a civil law conflict, the judicial act will objectively reflect the necessity to amend or supplement current.

\section{Discussion}

Opposing the opinion of legal scholars and practicing lawyers, who consider the analogy of law as an extraordinary (Bevzenko, 2010; Rovny, 2011) and exceptional (Balashov and Mishutina, 2009) tool, it seems possible to provide some solid arguments. There is a misguided concept that a qualitative improvement and a quantitative increase in the civil regulatory normative array as a whole reduces the necessity for law enforcers to apply the method under study for overcoming legal uncertainty.

Courts must make decisions that, while consistent with the letter of the law, also meet the requirements of socio-economic justice (Laptev, 2015). Judges must require legislators to disclose the consequences of approval of excessive amounts of compensation. Therefore, according to the rules of Article 333 of the Civil Code of RF regarding penalties, courts must consider analogous cases to assess (and if necessary, reduce) any civil law sanctions (Mikryukov, 2017). Civil law, which was developed to coordinate the behavior of independent individuals, is not able to keep up with the complexity of modern life. Individuals are able to enter into contractual obligations not specified by law and to create objects that do not conform to current regulatory statutes.

It is also obvious that general development and complication of the factors of civil law interaction provide new areas of implementation of the analogy of law, including: private relations that nowadays are insufficiently regulated, the application of genomic technologies (Maleina, 2019), introduction of robots (Arkhipov and Naumov, 2017) and artificial intelligence systems (Laptev, 2019), and the development of the digital economy as a whole (Vaipan, 2017). Being a channel of direct application of the basic principles of civil law, the analogy of law provides the necessity to include more actively civil law principles into the legal regulation of public relations.

Some scholars generally assume that legal principles constitute the analogy of law (Sizemova, 2015). The regulatory role of the analogy of law should not be underestimated in neither doctrinal nor practical aspects, since there actually observed general increase in the importance of civil law principles in the legal impact on public relations (Golubtsov, 2016), as well as the calls for their greater influence not only on the process of creating legal norms, but also on the practice of law enforcement (Bondarenko, 2013). Providing civil law impact on public relations according to the requirements of good faith, reasonableness and justice, the analogy of law becomes not only the means of gap overcoming, but also an effective way to resist the attempts of law evasion (Veter, 2015) and other abuse of law (Volkov, 2010). 
Judicial practice confirms the present consideration (the Resolution No. 67/10 of the Presidium of the Supreme Arbitration Court of RF dated April 27, 2010; the Resolution No. 12499/11 of the Presidium of the Supreme Arbitration Court of RF as of February 21, 2012). Such a vivid and significant feature of analogy as its direct contact with legal creativity (Taylor, 2009) implies the ability of the analogy of law to perform a creative function in the process of justice administration and to contribute to the development of law. It is not bad at all that there is some uncertainty, introduced into the sphere of civil law through the analogy of law providing a judge with certain discretion. Moreover, it is dialectically determined by the need for a regulatory system in such institutions that can minimize the gap between state legislative efforts and objective reality (Tsikhotsky, 2011). In this context, positive impact of the present feature of the analogy of law is clearly demonstrated by judicial acts of higher courts, which not only solved promptly the national wide-scale and high-profile problems, but also led to a relevant adjustment of current legislation.

The author of the present work points out the significance of the position of the Plenum of the Supreme Arbitration Court of RF declaring that justice and the general principles of civil law imply the inadmissibility of foreclosure on mortgaged movable property acquired on an indemnity basis from a mortgagor by a person who in good faith did not know, and should not have known that the acquiring property was encumbered with a pledge. The introduced provision contributed to the development of the "living" nature of the norm of Section 2 of Article 6 of the Civil Code of RF and to the understanding that the ability to anticipate normative changes is included in the analogy of law functional (Section 25 of the Resolution No. 10 of February 17, 2011 "On Certain issues of application of legislation on pledge”).

On the one hand, the Plenum is not actually authorized to make law, although it specified (for cases of acquisitions on good faith) the norm of Section 1 of Article 353 of the Civil Code of RF on the preservation of the pledge holder's rights, regardless of the category of the owner of the pledged property, and introduced a rule on the termination of the pledge right when the pledged property is transferred to the acquirer on good faith. On the other hand, the Plenum not only ensured the immediate application of the principles of civil law and protected a large number of car owners who bought cars pledged to banks, previously purchased by their counterparties on credit, but also anticipated the adoption of a new legal provision.

Nowadays (in the period after the adoption of the modern Civil Code of RF in 1994 until 2020), there is insufficient scientific research, as well as insufficient educational and methodological coverage of the cases, of the analogy of law implementation in civil law practice, although there is not any absence or shortage of such cases. Until recently, the "Martynyuk Case", considered in 1940 by the Supreme Court of the USSR, remained the only practical illustration of the theoretical construction of the application of civil legislation through the analogy of law (Ioffe, 2004). Law theorists and specialist in civil law were deprived of 

empirical material for the development of the analogy of law as an active, "living" institution. Therefore, there is an increase in the demand for the analogy of law in the administration of justice.

\section{Conclusion}

The results of this study confirm the idea of the current and inevitable in the future significance of the analogy of law in civil law practice. The ability of the analogy of law in law enforcement to perform a creative function and contribute to the development of law has been proven. Courts directly implementing the mechanism of the analogy of law in resolving a specific dispute are recommended not only to argue specifically the necessity of applying this mechanism in a judicial act, but also to give the legislator a clear and unambiguous signal on the necessity of specific legislative changes.

According to the analogy with the principle of intellectual intimidation attributed to Socrates the idea was confirmed that an increase in the normative array inevitably entails the contact of law with the legal void. Therefore, the increase in the number of disputes where law enforcers appeal to the analogy of law requires adequate consideration in the civilized research of lawmaking as well as in its educational process. It is necessary to intensify work on collecting, analyzing, and summarizing examples of the immediate implementation of the basic principles of civil law through the analogy of law.

\section{References}

Albov, A.P. (2013). Cultural norms of as the law source and form. Modern Lawyer, 4, 54-65. https://www.elibrary.ru/item.asp?id=20388062

Alieskerov, M. (2002). Procedural analogy in civil process. Russian Justice, 3, 18-20. http://base.garant.ru/5116996/

Andreev, V.K. (2020). Dynamics of Regulating Artificial Intelligence. Journal of Russian Law, 3, 58-68. DOI: $10.12737 /$ jrl.2020.030

Anisimov, V. F. (2016). A small opinion in a big discussion. Russian judge, 6, 56-57. https://www.elibrary.ru/item.asp?id=26254834

Arkhipov, V.V, Naumov, V. B. (2017). On some issues of the theoretical foundations of the development of legislation on robotics: aspects of will and legal personality. Law, 5 157170. https://www.elibrary.ru/item.asp?id=29144841

Balashov, A.N., Mishutina, E.I. (2009). The issues of the analogy of law and the legal analogy application in civil process. Russian Justice, 10, 59-62. https://elibrary.ru/item.asp?id=13025821

Bevzenko, R.S. (2010). The application of the Civil Code of the Russian Federation. Moscow: Yurayt 
Bogdanova E.E., Maleina M.N., Ksenofontova D.S. (2020) Certain Problems of Citizens' Rights Protection when Using Genomic Technologies. Lex russica, 5, 129-142. DOI: $10.17803 / 1729-5920.2020 .162 .5 .129-142$

Bondarenko, N.L. (2013). The modern methodological approach to the principles of civil law study. Bulletin of Perm University. Juridical sciences, 4, 305-309. http://www.jurvestnik.psu.ru/index.php/ru/vypusk-4222013

Braginsky, M.I., Vitryansky, V.V. (2001). Contract law. General Provisions. Moscow: Statut. D'amato, A. (2010). Legal Uncertainty. Northwestern Public Law Research, Paper No. 10-79. https://ssrn.com/abstract=1707826

Damele, G. (2014). Analogia Legis and Analogia Iuris: An Overview from a Rhetorical Perspective. Argumentation Library, 25, 243-256. DOI: 10.1007/978-3-319-06334$8 \_14$

Davis, K.E. (2011). The Concept of Legal Uncertainty. http://dx.doi.org/10.2139/ssrn.1990813

Demin, A.V. (2017). Discretion in Tax Law. Perm University Herald. Juridical Sciences. Issue 35. Pp. 42-55. https://ssrn.com/abstract=2945965.

Diogenes, L. (1979). On the life, teachings and sayings of famous philosophers. Myisl, Moscow: Academy of Sciences of the USSR, Institute of Philosophy.

Erokhova, M.A. (2014). Commentary to the Resolution of the Plenum of the Supreme Arbitration Court of the Russian Federation of April 4, 2014 N 22 On Certain Issues of Money Judgment to the Recoverer for Non-Execution of a Judicial Act. Bulletin of the Supreme Arbitration Court of the Russian Federation, 6, 32-53.

Ferrari, F., Bocharova, N. (2015). The astreinte in the Italian and Russian Administrative (Judicial) and Civil Proceedings. Russian Law Journal, 3, 9-45. https://doi.org/10.17589/2309-8678-2015-3-3-8-45

Golubtsov, V.G. (2016). The Principle of Good Faith as an Element of the Legal Mechanism for Stimulating the Debtor to Proper Execution of Obligations and Guaranteeing Creditors' Interests: Analysis of Judicial and Arbitration Practice. Juridical Sciences, 32, 175-184. DOI: 10.17072/1995-4190-2016-32-175-184

Hunter, D. (2008). Teaching and Using Analogy in Law. Journal of the Association of Legal Writing Directors, 2. https://ssrn.com/abstract=1089669

Ioffe, O. S. (2004). Selected Works. St. Petersburg.

Koszowski, M. (2017). Analogical Reasoning in Statutory Law. Journal of Forensic Research, 8. DOI: $10.4172 / 2157-7145.1000372$

Kulakov, V.V. (2013). Basic principles of civil law as a special form of law. Bulletin of Perm

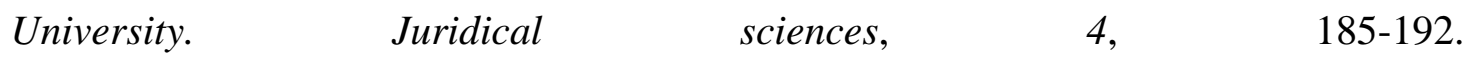
http://www.jurvestnik.psu.ru/index.php/ru/vypusk-4222013

Kuznetsova, O.A. (2006). Direct (immediate) impact of civil law principles. Notary, 1, 37-39. 
Laptev, V.A. (2015). Court decisions as part of judicial practice: application of the law and the principle of justness. Arbitration and civil procedure, 10, 28-33. https://elibrary.ru/item.asp?id=24350970

Laptev, V.A. (2019). Artificial Intelligence and Liability for its Work. Pravo. Zhurnal Vysshey shkoly ekonomiki, 2, 79-102. DOI: 10.17-323/2072-8166.2019.2.79.102

Luneva, E. (2015). The Trends in Development of Methodology of Scientific Cognition of Civil Legal Reality. Juridical Sciences, 3(29), 117-124. DOI: 10.17072/1995-4190-2015-3$117-124$

Macagno, F., Walton, D. (2009). Argument from Analogy in Law, the Classical Tradition, and Recent Theories. Philosophy and Rhetoric, 42(2), 154-182. https://ssrn.com/abstract=1742956

Maleina, M.N. (2019). The role of legal principles in eliminating and minimizing the risks of genomic technologies implementation. Lex russica, 8, 121-128. https://doi.org/10.17803/1729-5920.2019.153.8.121-128

Malyushin, A.A. (2015). Constitutional and judicial lawmaking (rights establishment) in the Russian Federation as a special form of modern lawmaking. Russian Justice, 10, 6-8. https://elibrary.ru/item.asp?id=24336861

Mikryukov, V.A. (2017). Limits of Analogy in the Mechanism of Judicial Reduction of Property Sanctions. Journal of Advanced Research in Law and Economics, 5(27), 1563 1575. https://journals.aserspublishing.eu/jarle/article/view/1715

Panova, I.V. (2012). Judicial process in the context of Russian legal culture. Bulletin of the Supreme Arbitration Court of the Russian Federation, 1, 74-84. https://elibrary.ru/item.asp?id=17215172

Plato. (2006). Works in four volumes. St. Petersburg: Publishing House of St. Petersburg University.

Polyakov, D.N. (2014). General ways of overcoming gaps in civil law. Bulletin of the Omsk Law Academy, 2(23), 54. https://elibrary.ru/item.asp?id=21545844

Raban, O. (2010). The Fallacy of Legal Certainty: Why Vague Legal Standards May Be Better for Capitalism and Liberalism. Boston University Public Interest Law Journal, 19(175). https://ssrn.com/abstract=1419683

Romanenko D. (2017) Legal Nature of Gaps in Anglo-American Common Law, Civil Law, 3, 40-42. https://www.elibrary.ru/item.asp?id=29322903

Rovny, V.V. (2011). Civil Law. Guide book in 3 vols. Moscow: RG Press.

Schauer, F., Spellman, B.A. (2017). Analogy, Expertise, and Experience. University of Chicago Law Review, 84(1). https://ssrn.com/abstract=3064100

Shindyapina, E.D., Boshno, S.V. (2006). Correlation of legal analogy and the analogy of law. Lawyer, 7, 6-9. 
Sizemova, O.B. (2015). About regulatory sources in the mechanism of legal regulation of interbank payments. Banking law, 4, 35-41. https://elibrary.ru/item.asp?id=23772275

Slepenkova, O.A. (2011). Some aspects of the application of civil law principles in judicial practice. Russian Justice, 9, 4-6.

Szabo, I. (1964). Socialist law. Moscow: Progress.

Taylor, G. (2009). Law and Creativity. Cambridge: Cambridge University Press.

Tsikhotsky, A.V. (2011). Institute of analogy in the mechanism of overcoming law gaps. Bulletin of Novosibirsk State University. Law, 2, 67-74 https://elibrary.ru/item.asp?id=17105162

Ulyanov, A.V. (2014). Good faith in civil law. Russian Law Journal, 6, 133-140.

Vaipan, V.A. (2017). Fundamentals of the legal regulation of the digital economy. Law and Economics, 11, 5-18.

Van Gestel, R., Micklitz, H.-W., Rubin, E.L. (2017). Rethinking Legal Scholarship: A Transatlantic Dialogue. New York: Cambridge University Press. http://dx.doi.org/10.2139/ssrn.2644088

Veter, N.Y. (2015). To the issue of the concept of the evasion of law. Power of the Law, 1, 155165. https://elibrary.ru/item.asp?id=24355585

Volkov, A.V. (2010). Formalism against subjectivity in civil law. Modern Law, 1, 35-39.

Weinreb, L. (2005). Legal reason: The use of analogy in legal argument. New York: Cambridge University Press. DOI: 10.1017/CBO9781316597774 